Bekkers, V.J.J.M, E-government and the emergence of virtual organizations in the public sector, in: Information Polity, vol. 8, 2003, nr. (3/4), pp. 89-102.

\title{
E-government and the emergence of virtual organizations in the public sector
}

\author{
Victor Bekkers
}

\section{Introduction}

The massive introduction and use of information and communication network technology in public administration has led to the establishment of a complex variety of new, virtual organization forms within and outside the public sector. Electronic government has been an important driver for the emergence of virtual organizations in the public sector.

However, our knowledge about these emerging forms of virtual organization has been limited, especially if we look at the public sector. Although the last ten years numerous studies have appeared systematic research into the world of virtual organizations is limited (Bekkers, 2000; Van Hout \& Bekkers, 2000).

In this article I want to grasp and understand the variety and complexity of virtual organizations in the public sector, which emerge in the slipstream of numerous egovernment initiatives. The development of an explorative typology of virtual organizations can help us to reduce this variety. Moreover, it can help to identify possible factors and relations between them which account for the similarities and differences between the identified types of virtual organizations. Relevant factors are related to specific characteristics of the ICT-network which is used, the socio-organizational network in which the virtual organization has emerged, and several types of egovernment services.

In section two I will describe e-government as a relevant phenomenon in public administration, which shows us how public administration is changing under influence of modern ICT. Virtual organizations are the manifestation of this change, but what does the notion of virtual organization imply? In section three I discuss some of the literature. In section four I will elaborate on the research strategy which has been followed in order to develop a typology of virtual organizations, which will be described in section five. In section six I will compare the specific types of virtual organization and relate them to specific e-government services, specific characteristics op ICT network and the socioorganizational network in which the virtual organization has emerged. Some conclusions will be formulated.

\section{The concept of e-government}

ICT is often seen as a set of tools which can help to reinvent government in such a way that existing institutional arrangements, in which the transactions and other interactions between government and its stakeholders are embedded, can be restructured and new 
arrangements can occur (Fountain, 2001; Heeks, 1999). These new arrangements are often introduced under flag of electronic government or e-government.

E-government is a policy and managerial concept, which has hardly any theoretical foundations, although there is a large amount of empirical research available which is focused on the effects of ICT on the functioning of public administration (Bellamy \& Taylor, 1997; Snellen \& Van de Donk, 1998; Fountain, 2001; Danziger \& Viborg Andersen, 2002). Due to this fuzzy variety of practices, the concept of egovernment is hardly defined and based on pragmatic experiences and visions.

E-government can be described as the use of modern ICT, at this moment especially internet and web technology, by a public organization to support or redefine the existing and/or future (information, communication and transaction) relations with 'stakeholders' in the internal and external environment in order to create added value (Bekkers, 2001; Moon, 2002). Relevant stakeholders are citizens, companies, societal organizations, other government organizations and civil servants (Gartner, 2000; Chadwick \& May, 2003). Added value can be found in increasing the access of government, facilitating the quality of service delivery, stimulating internal efficiency, supporting public and political accountability, and increasing the political participation of citizens.

E-government is often described in relation to the kind of services to be provided (Gartner, 2000; Fountain, 2001; Bekkers, 2001). Information services are focused on the disclosure of government information, for instance the possibility to download brochures, policy reports, regulations and other official documents. Contact services refer to the possibility to contact public administration For instance to ask questions to civil servants and politicians about the application of certain rules and programs, or to make a complaint. Transaction services refer to the electronic intake and further handling of certain requests and applications of personal rights, benefits and obligations, like digital tax assessments, the render of permits, licenses and subsidies. Participation services do not only address the possibility of electronic voting. Electronic forums and virtual communities can provide citizens a channel to get involved in the formulation and evaluation of policy programs, like the reconstruction of a neighborhood. The last kind of services are data transfer services which refer to the exchange and sharing of (basic and standard) information between public (and private) organizations.

The development of these services imply ICT-driven intra-organizational and interorganizational changes and arrangements, which can be described as the virtualization of public administration (Frissen, 1999; Fountain, 2001). Fountain (2001) describes this process as the rapid transfer, sharing and integration of information and communication processes and flows across organizational boundaries. Organizational boundaries begin to blur (Bekkers, 1998). The emergence of the virtual organizations in public administration is the result.

\section{The concept of virtual organization}

Looking at the literature about virtual organizations, one stumbles about a variety of definitions; a variety which does not stimulate systematic research into this new organizational phenomenon (Warner \& Witzel, 1999). In literature, virtual organizations are described by pointing out the following characteristics:

- The virtual organization as a network organization. In this approach the emphasis lies on the location-independent and temporary collaboration between separate 
organizations which is based on the notion of interdependency. Information and communication technology (ICT) supports the collaboration between these organizations by facilitating the exchange, distribution and sharing of information, knowledge, know how and other scarce and vital resources (Rockart \& Short, 1991; Davidow \& Malone, 1992; Byrne,1993; Picot et al., 1996; Sieber, 1997; Bellamy \& Taylor, 1998).)

- The virtual organization as fact and fiction. Virtuality points at the notion of "something appears to exist when in actuality it does not" (Martin, 1996:15). Picot et al. call it in German 'Als-ob-Organization' (Picot et. al., 1996:292). The virtual organization points at a situation where people or facilities that are not a part of an organization are linked to it as though they were. In this approach the emphasis lies on the contrast the between the people and resources which, in some situations, are apparently a part of the organization, while in other situations they are not.

- The virtual organization as an organization in cyberspace. Cyberspace specifically denotes the real and imaged space in which individuals meet in electronically mediated and simulated space (Holmes, 1997:234). The emphasis lies on the establishment of an 'information space', which is created through the connection of computers and computer networks. The creation of this space facilitates the sharing of information and knowledge, as well as electronic communication (O'Hara-Deveraux \& Johansen, 1994; Barnatt, 1995). This connection results in the creation of a space of flows, which is compressed in time ('timless time'). Castells (1996:412) describes virtual organizations as spaces of flows, which are the material organization of time-sharing social practices that work through flows (of information, capital, images, sounds, symbols and interactions) between organizations and people.

- The virtual organization as the organization of memory. Central is notion of the dynamic allocation of information processing capacity within a network of connected computers and computer networks. Time-sharing, made possible by the connection of computers and networks, enables the parallel disclosure and use of information and knowledge within a network. The interconnection of information processing capacities enables organizations to develop a common memory, across organizational boundaries (Mowshowitz (1992; 1994).

When we look at the literature on virtual organizations, we see that the attention is primarily focused on the virtual organization as a network organization, pointing out the changing nature of organizational boundaries. Network technologies facilitates processes of in- and exclusion of people and resources (Dawidow \& Malone, 1992). Hence, typologies of virtual organization forms are often focused on the description of specific patterns of network relations (Mintzberg, 1999). For instance, Campbell (1999) has distinguished the following types of virtual organizations: internal networks, stable networks, dynamic networks and web enterprises. However, the question can be posed if the network metaphor is distinctive enough to describe a virtual organization, because virtual organizations resemble too much the idea of a network organization. One reason reflects the idea that electronic networks and network organizations are in essence the same; or that a virtual organization mirrors the electronic network which is seen as the basis for the development of a virtual organization (McLoughlin \& Jackson, 1999). Other typologies are based on the combination of information-architecture and e-business models (Tapscott, 2000). Information architecture models, e-business models and models of virtual organizations are seen as three sides of the same triangle. For instance, the hub-model of the virtual organization, is an information-architecture model which facilitates logistical integration between the functions of separate organization (Mintzberg, 1999); an approach which implies that models of virtual organization are 
based on information planning models. In all these typologies a deterministic relationship is suggested between the structure of a virtual organization and the structure of electronic network and/or the information-architecture-model. However, one can doubt if this is a promising perspective.

\section{Research strategy}

In order to understand the variety and complexity of virtual organization in public administration, several steps have been made. However, it is important to bear in mind that the results of this research project are based on an explorative design, which will be used for further theoretical and empirical research.

First, it is necessary to develop a view on virtual organizations. I will define a virtual organization as a informational space that facilitates the sharing of information and knowledge, as well as electronic communication in order to support collective action. In doing this I choose for an instrumental and functional definition of virtual organizations. Virtual organizations can be seen as an instrument or a platform which enable people, groups, organizational units, or organizations to develop patterns of collective or concerted action (Thompson, 1967). In this view an organization can be seen as a set of coordination mechanisms. Hence, a virtual organization can be seen as a platform(s) which coordinates flows and processes of information and communication in order to create collective action between a group of actors. What kind of informational spaces have been developed in order to support e-government services that in most cases cross organizational boundaries? But, how can we describe these spaces? An understanding of the nature of coordination offers us the possibility to grasp a number of vital characteristics of the virtual organization (as a coordination mechanism).

Coordination can be described as a process of exchanging and processing information and/or a process of communication in order to achieve collective action (Thompson, 1967; Mintzberg, 1979). Sometimes this collective action is predetermined by a given and common goal, sometimes this common goal is not at hand and has to be developed. At least two dimensions are important. First, the degree in which the exchange of information and communication are formalized by the introduction of a hierarchy or by the development of (standardized) rules, routines and procedures, which sometimes can be automated. Secondly, it is important to look at those actors who are actually involved in the exchange of information and communication and thus play a role in the coordination activities. This dimension refers to the degree of inclusion or exclusion. On the basis of the two dimensions in a study has been made of e-government initiatives in the Netherlands.

The second step was to look at the relationship between technology and the form and functioning of virtual organizations. As mentioned earlier, it is important not to step in a trap by looking at virtual organization from a deterministic perspective, either by focusing to much on the characteristics of the ICT-network or infrastructure or the information architecture. Hence, attention should be paid to the interplay between the characteristics of the socio-organizational and ICT-network (Orlikowski \& Robey, 1991; McLouglin, 1999). Moreover, it is important to bare in mind that the characteristics of a already existing virtual organization will also influences the functioning and the socioorganizational network of actors, which uses the virtual organization and the possibilities the ICT-network offers. The complex interplay between technology and (virtual) can be 
seen as a process of co-evolution of social, political, institutional and technological factors (Pinch \& Bijker, et al. 1987; Nardi \& O’Day, 1999; McLoughlin, 1999).

What characteristics of the socio-organizational network in which a virtual organization is located, potentially influence the shaping of the virtual organization as coordination mechanism?. First, there is the degree of dependency or interdependency between actors with respect to the access and use of vital resources, like information and knowledge. Especial attention should be given to the existence of hierarchical center, which is able to determine the relations between the actors in the virtual organization (Rockart \& Short, 1991; Davidow \& Malone, 1992, Picot et al., 1993). Another factor is the institutional embedding of the virtual organization. The relations and dependencies between actors in a virtual organization, are also influenced by the specific institutional setting in which they operate, like the relationship with specific policy process, laws and regulations, grown practices, the history of a policy field, the political sensitivity of a policy sector, the fragmented structure of a policy field, or the degree of professionalism within a policy field (DiMaggio \& Powell, 1991). Both factors also influence the strategic behavior of the actors who are involved in the shaping of a virtual organization (e.g. Crozier \& Friedberg, 1980, McLouglin, 1999). What interests and domains are at stake and how do actors try to protect their influence? How is the game of played? Was there a clear ' win-win' situation, or was one actor able to impose its will? Thus, the politics of collective behavior is another issue to be addressed.

Looking at relevant characteristics of the ICT-network, attention should be paid to the nature of the ICT-infrastructure and dominant technology applications. For instance, EDI-technology has other characteristics than internet technology. EDI-like technology is heavily formalized, because it works with standardized data exchangeformats. This kind of technology offers more possibilities for standardization, formalization, fixed boundaries and even centralization of the coordination in the virtual organization (Kosynski, 1993). The specific qualities of the internet, based on open communication standards, facilitates coordination processes, which are based on mutual adjustment through electronic communication. Also, the information-architecture model which is used could be relevant. An information-architecture determines what kind information should be exchanged and how it should be exchanged. A referral index can be seen as an architecture which helps organizations to automatically exchange information, because precisely is determined which information of which organization is available and how it can be retrieved.

Scheme 1. The interaction between socio-organizational and ICT-networks in relation to the emergence of virtual organizations as an informational space

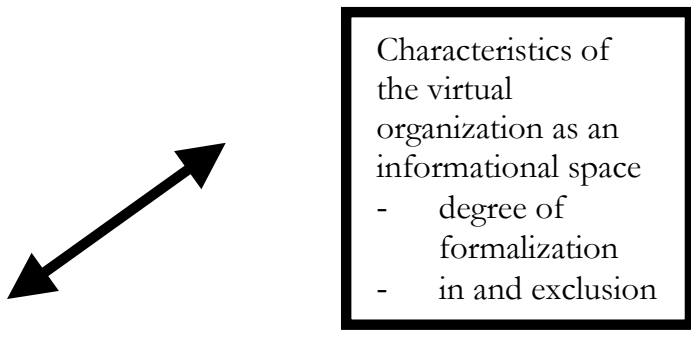

Characteristics of

the socio-

organizational

network of actors

degree of

(inter)dependen

cy

institutional

setting

strategic

behaviour

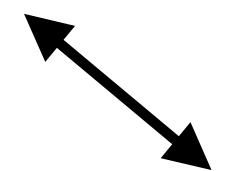

Characteristics of the ICT-network

nature of the infrastructure characteristics of the informationarchitecture 
The third step has been the study of e-government initiatives in the Netherlands and the virtual organization-like patterns which emerge around them. Especially, I have looked how informational spaces have been created, how these spaces are formalized and who has been participating in these spaces. Based on these research activities, a typology of virtual organization has been developed which will be presented in the next section. Several 'Idealtypen' will be sketched. The next step is to relate this description of the shape and functioning of these 'Idealtypes' of virtual organization to the interplay of the characteristics of ICT network and socio-organizational network. What are relevant factors and relations between them? In section six a preliminary explanation is given.

A last remark on the generalization of the research findings, if we relate them to the Dutch examples which has been used. The emphasis lies on the development of a theoretical and analytical framework to understand the variety of virtual organizations in public administration and not on 'statistical' and empirical generalization. Further research should determinate if country specific characteristics (as relevant institutional characteristics of the socio-organizational network in which a virtual organization emerges) influence the shape and functioning of the virtual organization. The same line of reasoning can be used for a comparison with virtual organization in the private sector. It is possible that the typology of virtual organizations can also be used in the private sector. However, this was not the starting point of this research. Further research should elaborate this kind.

\section{A typology of virtual organizations}

On the basis of a study of numerous e-government initiatives in the Netherlands and a description of the information spaces which were created, I have been able to develop a typology of virtual organizations. This typology is based on two dimensions: the degree of formalization and the openness of the in- and exclusion process of virtual organization as an information space. A 2-by- 2 typology has usually four types, but I found five types.

Scheme 2. A typology of virtual organizations, defined as informational spaces which facilitate concerted action

\section{Degree of formalization}

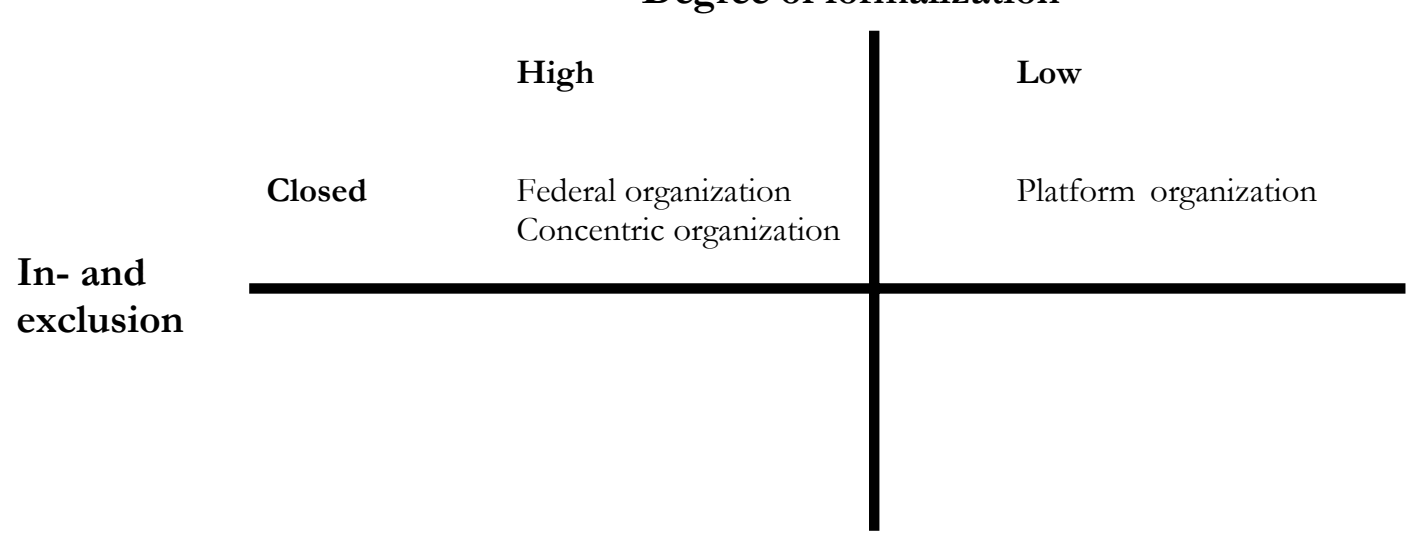


In the description of each organization type the following elements play a role. Each type will be described and illustrated with an example. Attention is paid to the formalization of the information exchange and communication processes, while I have also looked at the way actors can participate in the information space which has been created. A brief description is also given of the ICT infrastructure and architecture that is used.

Moreover, I will try to give an brief indication of the socio-organizational network in which this type of virtual organization has emerged. Moreover, I have tried to visualize the way in which the coordination takes places in each of described organization types.

\section{The federal virtual organization}

The Zealand Harbor Information System (ZHIS) is an example of a virtual organization in the Dutch ports of Vlissingen en Terneuzen. The ZHIS is a highly formalized electronic EDI-network, which facilitates the exchange of information and coordination between a variety of public and private organizations with different tasks and responsibilities in order improve their quality of services. Before its introduction, organizations like the Port Authority, the Coast- Guard, the Customs Office, the PilotService, transport companies, in-and export agencies and stevedores, which handle aspects of the arrival, the (un)loading and departure of ships in the harbor, had to contend with several communication and coordination problems. The logistical planning and transparency of the harbor was not efficient, because every organization used different arrival and departure times. Tasks and working processes could not be integrated. The new system has enabled a better planning and handling of logistical and administrative tasks, routines and procedures, which in the case of the public organizations are based on the execution and enforcement of public rules and regulations. This was the common goal of all actors.

Scheme 2. The federative virtual organization

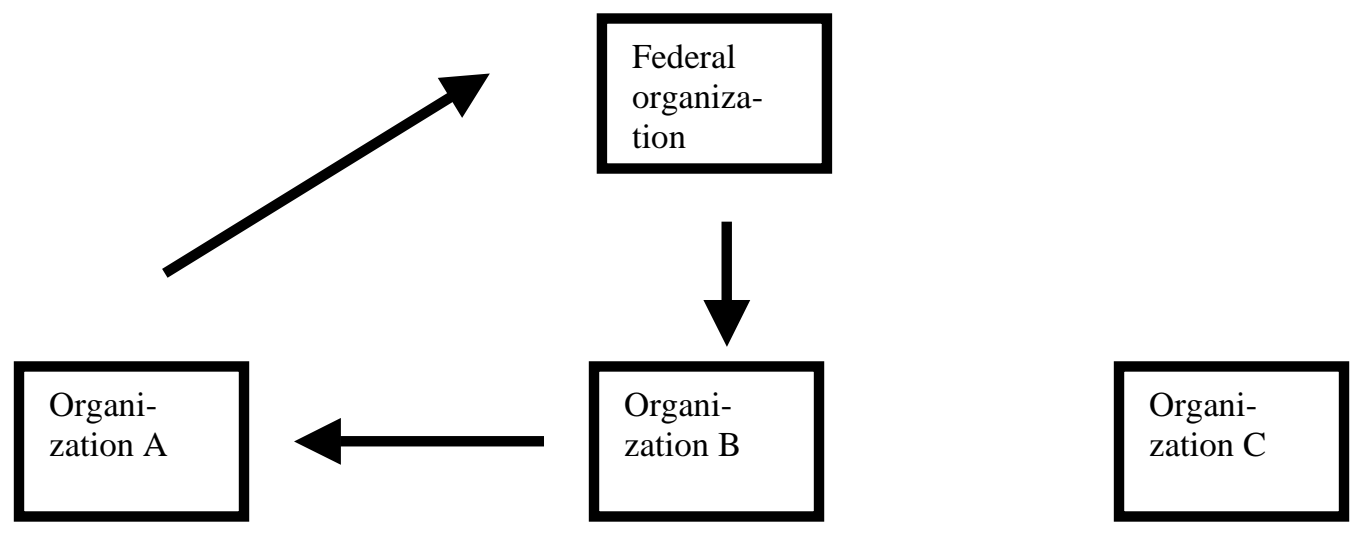

The ZHIS is a federative virtual organization. The autonomy en variety of the participating organizations (the 'States') is respected. They are responsible for the content and exploitation of their own information systems and related working processes. However, these organizations recognize the interdependencies between them. They 
acknowledge that they can improve the efficiency and efficacy of their task performance, if they share information. Through the introduction of a third party, called ZHIS Central as the federate level, a shared information space is created. This third party operates as an 'information broker' (as the dominant information architecture model) which coordinates the information exchange between the participating organization. Questions are send to the 'information broker', which will direct the question to the organizations which are able to answer the specific question. The information broker -ZHIS Centralcan be seen as a super-ordinate organization with a specific task: creating a shared information space within the ports of Vlissingen en Terneuzen.

In the realization of the ZHIS the Port Authority has plaid an important role. It took the initiative and presented a business case to the other actors which made clear what the content of the 'win-win' was and how this could be achieved. The ownership of the ZHIS is in the hands of all the parties involved.

\section{The virtual concentric organization}

The virtual organization as a concentric organization can be described as an information space which is created by the coupling of databases. Around these databases concentric circles of users can be identified, which are located within and outside the organization. Network technology facilitates real-time and online accessibility. These circles of user groups can process and share the information in the databases at the same time, parallel of each another (Zuboff, 1988). The information-architecture which was based on the parallel processing of information, tries to explore the benefits of database technology. The processing activities are highly regulated and restricted to specific users and user groups.

Scheme 3. The virtual concentric organization

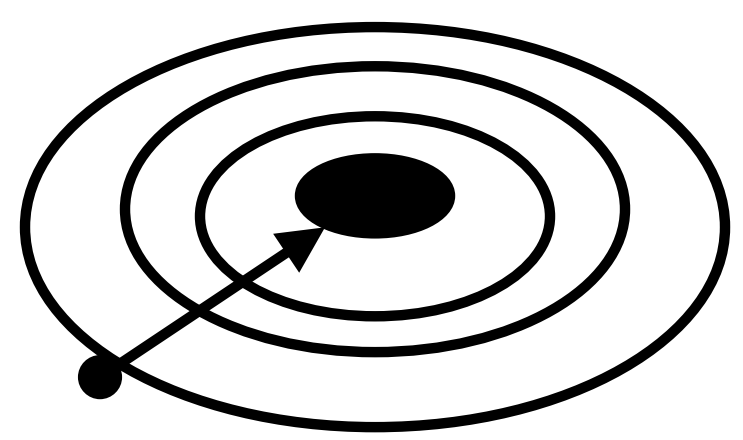

In the Dutch public sector the Student Loans Administration is a concentric

organization. An informational heart is created through the coupling of databases, which is accessible for front and back office employees as well as students who want to look at and alter (to a limited degree) their own data. The students form outermost circle of users. The retrieval and altering of the information in the databases is highly formalized and secured and the access to the database is limited to specific users groups, which use the intranet or the internet.

Another example is the Dutch Vehicle License Registration Agency, which also plays a role in the safety inspection of cars. This inspection of cars, older than 3 years, is carried out by local and private garages. These garages have access to the specific inspection register. The actual inspection process is formalized and controlled by the information format, which they exchange with the Vehicle License Registration Agency. The agency uses primarily an information architecture which enable them to monitor the 
discretion of the local garages from a central point, while exchange of information takes place through the network of a third party - the network of the association of garages.

Both examples show that through the intervention of a dominant actor, which plays an important role in the execution and monitoring of public rules and regulations, an informational space is created, which enables this central actor to control the information processing behavior of groups within and outside the focal organization.

\section{The virtual platform organization}

In the platform organization a digital platform is created, which can be seen as a space for sharing of information and knowledge as well as a virtual meeting place for communication and interaction.

COPS is an example of a virtual platform organization, based on extranet technology. A closed information and communication domain is created, which enables civil servants with criminal investigation competencies and located in a variety of organizations with specific tracking and tracing tasks (police, tax administration, animal protection etc.) to share information and to communicate with one another about their profession and professional development. For instance, within a secured area of COPS, the platform was used for writing a policy report on how to improve the efficacy of detective work and methods of the criminal investigation departments. Another example is the platform of experts who discussed the proposals which were made during the Convention of Europe. The internet gave them access to platform, for which one has to apply and for which guests have been invited to give their opinion.

The communication and information exchange processes within the platform are not highly formalized. There is an open, unstructured communication, while the access to the platform is regulated. One has to be a member of a certain group to participate in the platform.

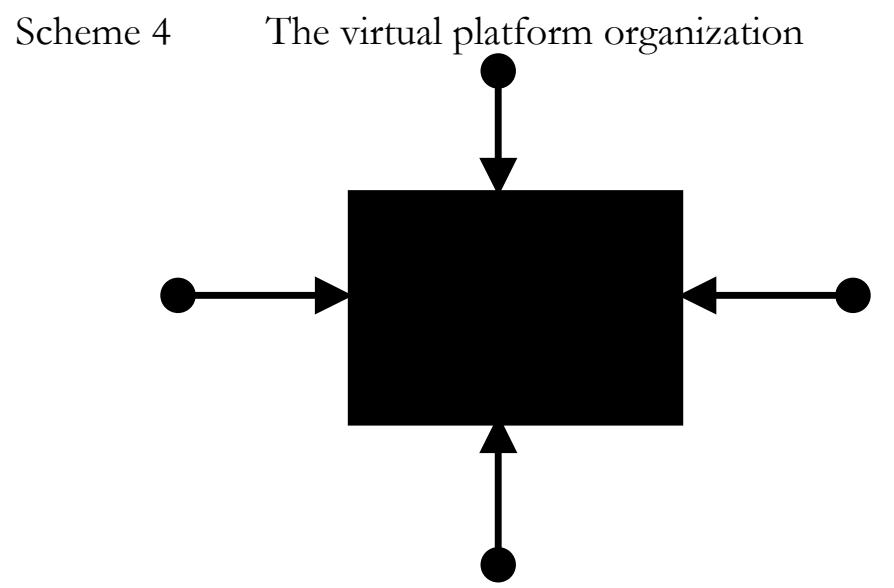

The participation in the platform and is based on interdependency. Participants recognize that the sharing and exchange of information, knowledge and idea, could improve their own understanding. Moreover, it facilitates a process of mutual adjustment and shared understanding, which can stimulate collective action. Most platforms can be found in formulation and evaluation phase of the policy process.

\section{The portal organization}

In the portal organization an information space is also created. Information and other sources of knowledge are brought together as well as links which lead to other information sources. The architecture-model is based on the principle of linking, while also content management systems and models play an import role. 
In the Netherlands www. overheid.nl (www.government.nl) functions as the gateway to Dutch public administration, which tries to enhance the transparency and access of public administration. Using several target group oriented entrances - like citizens, politicians and civil servants - information can be gained about the central, local and regional government agencies. It is also possible, using 'deep linkages', to connect to web-enabled information resources, which are administered by those agencies and which are located in their back offices. Sometimes portal organizations are also used for transactions purposes, like the applying for permits, subsidies and the assessment of taxes. In the Netherlands we see that local virtual counters, focused on themes like 'living and building', 'care and welfare' and 'business', are created which are based on the portal concept.

The interactions which take place within the portal organization are mostly structured and formalized, like the number and content of resources, the number and kind of links, the organization of the search functions and for instance the electronic form which could be used to order products of to ask for certain services. The access to the portal as information space is in most cases free. The establishment of these egovernment portals are mostly based on the notion of interdependency. The notion of integrated, electronic public service delivery, which is at the heart of many e-government programs in the Netherlands and in other countries, is an important driver for organizations to share information in a portal.

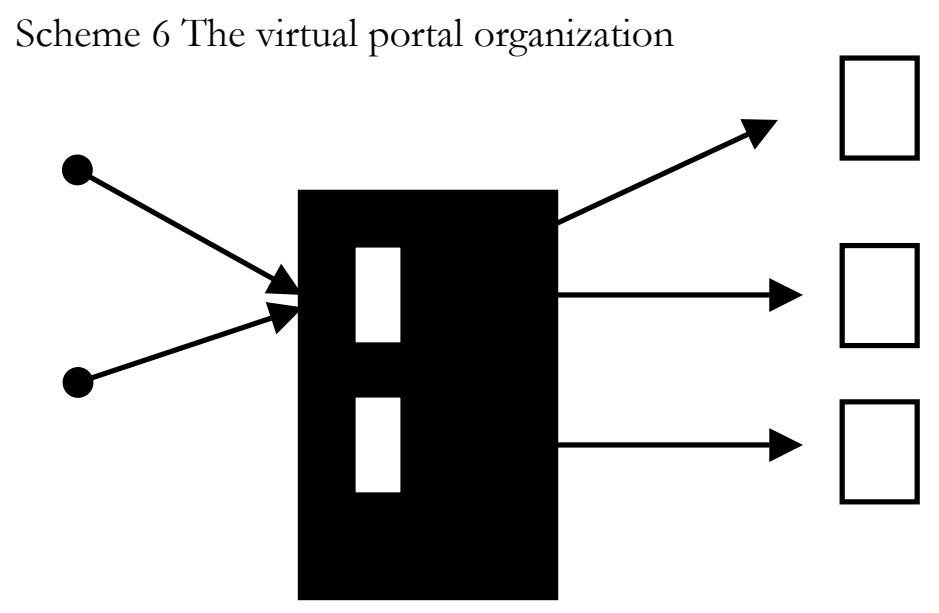

\section{The virtual web organization}

The last type of virtual organization is the web organization. News and discussion groups on the internet as well as virtual communities are illustrations of the web organization. Schalken (1999) has described in detail such a group, a group of biker enthusiasts (www. motorfiets.nl). For bikers this open discussion group is a source of information and a platform for communication about serious, policy-oriented issues - like security or changing legislation - and leisure and fun issues - like Harley Davidsons. Input from these discussions is often used by certain interest groups to influence the policy making process. Moreover, it can be noticed that parallel to an official electronic discussion forum, alternative and open discussion groups are started in which a lively debate exists about policy proposals (Schalken, 1999).

Scheme 6. The virtual web organization

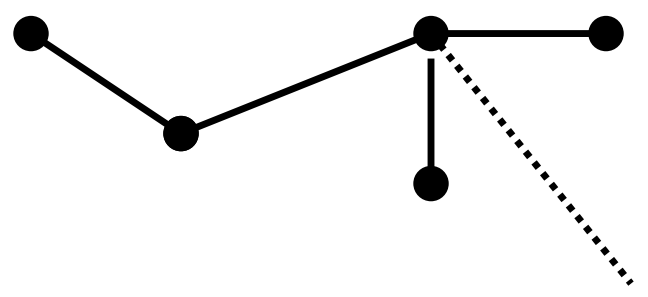




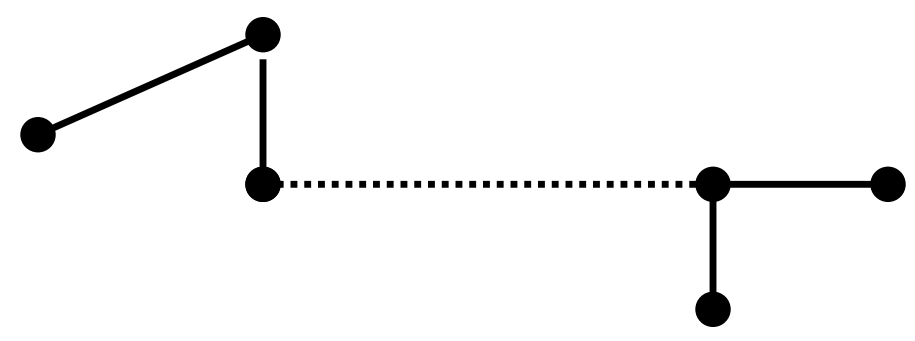

Discussion groups can be seen as loosely coupled interactions and relations between discussants which created a shared information space. The internet can be see as an infrastructure that enables people to organize themselves as a group, to explore the issues which appeal to common interests. Self-organization and goal searching, which takes places through communication and interaction, are two important characteristics of the web organization. Frissen (1999) has used the metaphor of a rhizome to describe the form and functioning of this type of virtual organization. The rhizome is a root-system which fibers grow even faster, in all directions, then they die. When somebody is disappointed in a discussion or wants to explore a related issue, he will leave or he will start his own discussion, which will attract other new members. The result is a myriad of interrelated and isolated discussion and sub discussion groups.

\section{Synthesis}

Comparing the several types of virtual organization the following pictures can be derived. First, I have related the organization types to e-government services which have been discerned in section two, the dominant coordination mechanism, the degree of formalization and the process of in and exclusion.

Table I. Virtual organization types related to e-government services and coordination type

\begin{tabular}{|c|c|c|c|c|c|}
\hline $\begin{array}{l}\text { Virtual } \\
\text { organization }\end{array}$ & Federal & Concentric & Platform & Portal & Web \\
\hline $\begin{array}{l}\text { Dominant e- } \\
\text { government } \\
\text { service }\end{array}$ & $\begin{array}{l}\text { Datatransfer } \\
\text { services, } \\
\text { sometimes } \\
\text { extended with } \\
\text { transaction } \\
\text { services }\end{array}$ & $\begin{array}{l}\text { Datatransfer } \\
\text { services, } \\
\text { sometimes } \\
\text { extended with } \\
\text { transaction } \\
\text { services }\end{array}$ & $\begin{array}{l}\text { Contact and } \\
\text { participation } \\
\text { services }\end{array}$ & $\begin{array}{l}\text { Information and } \\
\text { contact services, } \\
\text { sometimes } \\
\text { transaction }\end{array}$ & $\begin{array}{l}\text { Contact and } \\
\text { participation } \\
\text { services }\end{array}$ \\
\hline $\begin{array}{l}\text { Dominant } \\
\text { coordination } \\
\text { mechanism }\end{array}$ & $\begin{array}{l}\text { Exchange and } \\
\text { disclosure of } \\
\text { information in } \\
\text { relation to a well } \\
\text { defined goal }\end{array}$ & $\begin{array}{l}\text { Processing and } \\
\text { disclosure of } \\
\text { information in } \\
\text { relation to a well } \\
\text { defined goal }\end{array}$ & $\begin{array}{l}\text { Sharing of } \\
\text { information and } \\
\text { knowledge and } \\
\text { communication } \\
\text { in relation to an } \\
\text { emergent goal }\end{array}$ & $\begin{array}{l}\text { Exchange an } \\
\text { disclosure of } \\
\text { information; } \\
\text { sometimes } \\
\text { transaction in } \\
\text { relation to a } \\
\text { broader theme } \\
\text { or target group }\end{array}$ & $\begin{array}{l}\text { Sharing of } \\
\text { information and } \\
\text { knowledge and } \\
\text { communication } \\
\text { in relation to an } \\
\text { emergent goal }\end{array}$ \\
\hline $\begin{array}{l}\text { Degree of } \\
\text { formalization }\end{array}$ & $\begin{array}{l}\text { Formalization } \\
\text { and } \\
\text { standardization } \\
\text { of process and } \\
\text { content }\end{array}$ & $\begin{array}{l}\text { Formalization } \\
\text { and } \\
\text { standardization } \\
\text { of process and } \\
\text { content }\end{array}$ & $\begin{array}{l}\text { Formalization of } \\
\text { access, not of } \\
\text { the exchange } \\
\text { and } \\
\text { communication } \\
\text { process }\end{array}$ & $\begin{array}{l}\text { Formalization of } \\
\text { the linking and } \\
\text { searching } \\
\text { process, as well } \\
\text { as the delivery } \\
\text { formats of } \\
\text { content }\end{array}$ & $\begin{array}{l}\text { No } \\
\text { formalization }\end{array}$ \\
\hline In- and & Regulation of in- & Regulation of in- & Regulation of in- & No regulation & No regulation \\
\hline
\end{tabular}




\begin{tabular}{|l|l|l|l|l|l|}
\hline $\begin{array}{l}\text { exclusion of } \\
\text { parties }\end{array}$ & $\begin{array}{l}\text { and exclusion; } \\
\text { restricted number }\end{array}$ & $\begin{array}{l}\text { and exclusion; } \\
\text { restricted } \\
\text { number }\end{array}$ & and exclusion & & \\
\hline
\end{tabular}

It is interesting to see that, apparently, there is a relationship between the rather heavy regulated and restricted federal and concentric types of virtual organizations and predominantly datatransfer (and to some extent transaction. The sensitivity of the exchange processes is a possible explanation. Very often additional demands are put forward, because the integrity of the data is at stake, especially when agencies act upon these data in relation to the distribution of rights and obligations. Another reason is that federal and concentric organizations challenge the information domains of separate organizations. (Bellamy \& Taylor, 1998). They affect the autonomy of these organizations and the regulation of information relations is used to protect this autonomy.

In table 2 I have relate the types of virtual organization to a number of characteristics of the socio-organizational network

Table 2. Relationships between types of virtual organization and characteristics of the socioorganizational network

\begin{tabular}{|c|c|c|c|c|c|}
\hline 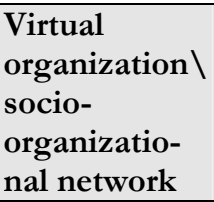 & Federal & Concentric & Platform & Portal & Web \\
\hline $\begin{array}{l}\text { Degree of } \\
\text { dependency }\end{array}$ & Interdependency & Dependency & Interdependency & Interdependency & $\begin{array}{l}\text { Horizontal } \\
\text { relation }\end{array}$ \\
\hline $\begin{array}{l}\text { Existence of a } \\
\text { (hierarchical } \\
\text { center) }\end{array}$ & Center & Center & Center & Center & No center \\
\hline $\begin{array}{l}\text { Institutional } \\
\text { embeddedness } \\
\text { the policy } \\
\text { process }\end{array}$ & $\begin{array}{l}\text { Implementation } \\
\text { of policy } \\
\text { programs } \\
\text { Execution and } \\
\text { enforcement of } \\
\text { rules } \\
\text { Strong } \\
\text { embeddedness }\end{array}$ & $\begin{array}{l}\text { Implementation } \\
\text { of policy } \\
\text { programs } \\
\text { Execution and } \\
\text { enforcement of } \\
\text { rules } \\
\text { Strong } \\
\text { embeddedness }\end{array}$ & $\begin{array}{l}\text { Policy } \\
\text { development } \\
\text { and evaluation } \\
\text { Strong } \\
\text { embeddedness }\end{array}$ & $\begin{array}{l}\text { The whole policy } \\
\text { process, but with } \\
\text { an emphasis on } \\
\text { policy } \\
\text { implementation } \\
\text { and service } \\
\text { delivery- } \\
\text { Strong } \\
\text { embeddedness }\end{array}$ & $\begin{array}{l}\text { Policy } \\
\text { development } \\
\text { and evaluation } \\
\text { No } \\
\text { embeddedness }\end{array}$ \\
\hline $\begin{array}{l}\text { Strategic } \\
\text { behavior }\end{array}$ & Win-win & Imposing & Win-win & Win-win & Win-win \\
\hline
\end{tabular}

This table show us that platform and web organizations often are related to the development and evaluation of public policies, in which discussion and thus communication plays an important role. In the federative, platform and portal organization interdependency seems to be an important force to find a win-win situations which legitimizes the establishment of a common information space that partially integrates different information domains. The concentric organization creates an informational space which goes beyond its own organizational boundaries - redefining the process of inclusion - because it has the power to do so. In the web organization the sharing of information, knowledge and communication takes place on a voluntary basis. Successful sharing and meaningful communication is based on the creation of shared understanding about policy issues.

Tabel 3 Relationships between types of virtual organization and characteristics of the ICTnetwork 


\begin{tabular}{|c|c|c|c|c|c|}
\hline 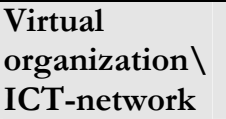 & Federal & Concentric & Platform & Portal & Web \\
\hline $\begin{array}{l}\text { Nature ICT- } \\
\text { network }\end{array}$ & $\begin{array}{l}\text { Closed and } \\
\text { formalized } \\
\text { (mostly EDI- } \\
\text { like) }\end{array}$ & $\begin{array}{l}\text { Closed and } \\
\text { formalized } \\
\text { (intra- and } \\
\text { extranet) }\end{array}$ & $\begin{array}{l}\text { Closed (extranet) } \\
\text { and open } \\
\text { (internet) }\end{array}$ & Open (internet) & Open (internet) \\
\hline $\begin{array}{l}\text { Dominant } \\
\text { information - } \\
\text { architecture } \\
\text { model }\end{array}$ & $\begin{array}{l}\text { Information } \\
\text { broker/referral } \\
\text { index model }\end{array}$ & Database model & Platform & $\begin{array}{l}\text { Linking and } \\
\text { content } \\
\text { management } \\
\text { models }\end{array}$ & Rhizome \\
\hline
\end{tabular}

Attention should also be paid to the relationship between the type of virtual organization and characteristics of the ICT-network. The need to formalize relationships in a socioorganizational network is sometimes reflected in a highly formalized ICT-network (like EDI) and in the information-architecture which is used. This can be observed in the concentric and federal organization. One reason for mutual formalization is that is concerns information exchange and processing activities which relate to the implementation of policy program or the execution and enforcement of rules on which the allocation of rights and obligations is based. The use of formalized information architecture-models, can also be seen as an expression to protect the autonomy of the information domains which are at stake. This can be observed in the concentric, the federal and portal organization.

This typology should be seen as a heuristic instrument which can help us to improve our theoretical and empirical understanding of virtual organizations in public administration, which are hardly and systematically been investigated. It is a description which tries to make an inventory of characteristics and relationships between them. Further research should investigate if the relationships which have been described, actually exist.

Moreover, the typology offers us the possibility to look for transition patterns and push and pull factors which can account for the hybrid characteristic of many virtual organizations (Mintzberg, 1979). Under what conditions does a web organization develop itself into a platform organization and vice versa. Such a transition process can interpreted as a process of (de-) institutionalization of changing perceptions of (inter)dependency, which lead to a changing process of in- and exclusion.

However, the over-emphasis of the characteristics of a specific type can also be a risk. There is always a tension between the descriptive clarity of the typology and the ambiguity of reality in which all kinds of combinations of virtual organization types occur.

Further research should determine how stable this typology will be or how it can be elaborated. However, it is a first step in trying to understand, on a rather basic level, what kind of virtual organizations are emerging in the slipstream of e-government. Moreover, it can provide a better understanding of e-government itself, because the theoretical foundations of e-government are not well elaborated.

\section{Literature}

Barnatt, Ch. (1995), Office Space, cyberspace and virtual organization, in: Journal of General Management, vol. 20, nr. 4, Summer, p. 78-91.

Byrne, W. (1993), The virtual corporation, in: Newsweek 8 February 1993, pp. 98-103. 
Bekkers, V.J.J.M.(1998), Wiring public organizations and changing organizational jurisdictions, in: Snellen, I.Th.M. \& W.B.J.H. van de Donk (eds.), Public administration in an information age, IOS Press, Amsterdam/Berlin/Oxford/Tokyo/Washington, pp.57-78.

Bekkers, V (2000) Voorbij de virtuele organisatie? Over de bestuurskundige betekenis van virtuele variëteit, contingentie en parallel organiseren. Elsevier, Den Haag.

Bekkers, V. (2001), De strategische positionering van e-government In: Van Duivenbode, H. \& M. Lips (eds.), Klantgericht werken bij de overheid, Utrecht, pp. 4966.

Bellamy. Ch. \& J. Taylor (1998), Governing in the information age, Open University Press, Buckingham.

Chadwick, A. \& C. May (2003), Interaction between states and citizens in the age of the internet: 'e-Government' in the United States, Britain and the European Union, in:

Governance, vol. 16., no: 2, pp. 271-300

Campbell, A. (1999), Knowlegde management in the web enterprise, in: Jackson, P. (ed.), Virtual working: social and organizational dynamics, Routledge, London/New York, 1999, pp. Pp. 21-31.

Castells, M. (1996), The rise of the network society. The information age: economy, society and culture, vol. 1., Blackwell, Oxford.

Crozier, M. \& Friedberg, E. (1980), Actors and systems. The politics of collective action, University of Chicago Press, Chicago.

Danziger, J. \& K. Andersen (2002), The impact of information technology on public administration, in: Journal of Public Administration, vol. 25, no: 5, pp. 591-627.

Davidow, W. \& M. Malone (1992), The virtual corporation, Harper, New York.

DiMaggio, P. \& Powell,W. (1991), The new institutionalism in organizational analysis, CUP, Chicago.

Fountain, J. (2001), Building the virtual state. Information technology and institutional change, Washington D.C.

Frissen, P. (1999), Politics, governance and technology, Elgar, Cheltenham.

Gartner, (2000) New rules and realities in e-government, www.gartner.com

Heeks, R. (eds.) (1999), Reinventing government in the information age, London/New York

Holmes, D. (1997), Introduction: Holmes, D. (ed.), Identity and community in cyberspace, Sage, London, pp. 1-25.

Hout, E.J.Th. van \& V.J.J.M. Bekkers (2000), Patterns of virtual organization: the case of the National Clearinghouse for Geografic Information, in: Information Infrastructure and Policy, vol. 6., nr. 4., pp. 197-207.

Kosynski, B. (1993), Strategic control in the extended enterprise, IBM Sysetms Journal, vol. 32, no. 1, pp. 111-142.

Martin, J. (1996), Cybercorp, Amacon, New York.

McLoughlin, I. \& P. Jackson (1999), Organizational learning and the virtual organization, in: : Jackson, P. (ed.), Virtual working: social and organizational dynamics, Routledge,

London/New York, pp. 178-192.

McLoughlin, I. (1999), Creative technological change, Routlegde, London.

Mintzberg, H. (1979), The structuring of organizations, Prentice Hall, Englewood Cliffs.

Mintzberg, H. (1999), Organigraphics. Drawing how companies really work, in: Harvard Business Review, p. 87-94.

Moon, M. (2002), The evolution of e-government among municipalities: rhetoric or reality?, in Public Administration Review, vol. 62, no:4, pp. 424-433.

Morgan, G. (1986), Images of organization, Sage, Beverly Hills. 
Mowshowitz, A. (1992), Virtual feudalism, A vision of political organization in the information age, in: Informatization in the public sector, vol. 2, nr. 3, pp. 213-232. Mowshowitz, A. (1994), Virtual organization: a vision of management in the information age, in: The Information Society, vol. 10, pp. 267-288.

Nardi, B. \& V. O’Day (1999), Information ecologies, Cambridge, Mass..

O’Hara \& R. Johansen (1994), Global work. Bridging distance, time and culture, JosseyBass, San Francisco.

Orlikowski, W. \& D. Robey (1991), Information technology and the structuring of organization: in: Information systems research, vol. 2, no; 2, pp. 143-171.

Pinch, T. \& W. Bijker (1987), The social construction of facts and artifacts, in: Bijker, W.E., Th. P. Hughes \& T. Pinch (eds.), The social construction of technological systems, Cambridge Mass, pp. 17-50.

Picot, A., R.. Reichwald \& R.. Wigand (1995), Die grenzenloze Unternehmung, Gabler, Wiesbaden.

Rockart, J. \& J. Short (1991), The networked organization and the management of interdependencies, in: Scott Morton, M. (ed.), The corporation of 1990s, Oxford University Press, New York/Oxford, pp. 189-219.

Schalken, K (1999) Motorfietsen op het digitale verkeersplein, in: Bestuurskunde, nr.5, pp. 210-218.

Sieber, P. (1997), Internet-Unterstützung virtueller Unternehmungen, in: G. Schreijögg \& J. Sydow (Hrsg.), Gestaltung von Organisationsgrenzen, De Gruyter, Berlin.

Snellen, I. \& W. van de Donk (eds.) (1998), Public administration in an information age, IOS Press, Amsterdam.

Tapscott, D. (1996), Digital economy, McGraw Hill, New York.

Tapscott, D., D. Ticoll \& A. Lowry (2000), Digital capitalism, Nicolas Brealey Publ., London/Nashville.

Thompson, J. (1967), Organizations in action, McGraw Hill, New York.

Warner. M. \& M. Witzel (1999), The virtual manager, in: Journal of General

Management, vol. 24, no. 4, pp.71-92.

Zuboff, S. (1988), In the age of the smart machine, Heineman, Oxford.

\section{About the author}

Victor Bekkers is professor of public administration at the Erasmus University in Rotterdam, the Nethlerlands. He wants to thank dr Vincent Homburg for his comments on earlier drafts of the article. 